(c) American Dairy Science Association, 2005.

\title{
Technical Note: Molecular Typing of Corynebacterium bovis Isolates by Pulsed-Field Gel Electrophoresis
}

\author{
D. García-Crespo, ${ }^{1}$ J. Navas, ${ }^{2}$ G. Gradillas,${ }^{3}$ and R. A. Juste ${ }^{1}$ \\ ${ }^{1}$ Dpto. de Sanidad Animal, NEIKER-Instituto Vasco de Investigación y Desarrollo Agrario, \\ Berreaga, 1. 48160 Derio, Bizkaia, Spain \\ ${ }^{2}$ Departamento de Biología Molecular (Unidad Asociada al C.I.B., CSIC), Facultad de Medicina, \\ Universidad de Cantabria, Herrera Oria s/n, 39011 Santander, Spain \\ ${ }^{3}$ Servicio de Laboratorio y Control, Consejería de Ganadería, Agricultura y Pesca, \\ Gobierno de Cantabria, Peña Bejo s/n, 39011 Santander, Spain
}

\section{ABSTRACT}

A typing method for Corynebacterium bovis based on pulsed-field gel electrophoresis (PFGE) is described and applied to type 162 strains isolated from mastitic milk from 57 Friesian dairy herds in northern Spain. Isolates were identified to the species level using the API-Coryne system and a polymerase chain reaction-restriction fragment length polymorphism of the $16 \mathrm{~S}$ rDNA amplicon. Cultures in logarithmic phase were harvested, mixed with agarose, and treated with lisozyme and proteinase $\mathrm{K}$ to release intact genomic DNA that was di-

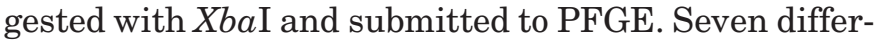
ent pulsotypes were identified; none of them were similar to that of the reference strain (ATCC 7715). The most frequent pulsotype was pattern I (51.9\%) followed by pattern II (29.6\%). The majority of the herds showed infection with one single pulsotype, but 12 herds yielded 2 pulsotypes, and one herd had 3 pulsotypes. No relationship was found between the geographical location of the herd and the pulsotype. This is the first description of a typing method for C. bovis; the technique might prove useful for epidemiological studies on this species. (Key words: Corynebacterium, Corynebacterium bovis, mastitis, pulsed-field gel electrophoresis)

Abbreviation key: PFGE = pulsed-field gel electrophoresis, $\mathbf{T E}=$ Tris/HCl-EDTA .

Corynebacterium bovis is the most frequently isolated coryneform from bovine mammary glands (Watts, 1988). Many bacterial pathogens can infect the bovine mammary gland, and $C$. bovis is considered a minor pathogen by many researchers despite its increasing prevalence (Hillerton, 2000). Although some authors describe $C$. bovis as a cause of clinical bovine mastitis (Boyer, 1998), there is much debate about the contribu-

Received October 8, 2004.

Accepted January 28, 2005.

Corresponding author: R. A. Juste; e-mail: rjuste@neiker.net. tion of this bacterium to the disease and its virulence properties (Lam et al., 1997; Schukken et al., 1999). Corynebacterium bovis is also a sporadic, opportunistic agent of disease in humans (Bernard et al., 2002). Given the controversy surrounding the role of $C$. bovis in the epidemiology of bacterial mastitis, it is important to determine whether there are differences between $C$. bovis isolates that might be related to special virulence properties or protection against other mammary pathogens. Here, we propose a pulsed-field gel electrophoresis (PFGE) method for the typing of $C$. bovis isolates. Some authors consider PFGE as the "gold standard" among molecular typing methods for bacteria (Singleton, 2000), and PFGE has been used to type numerous pathogenic microorganisms including other species of Corynebacterium such as C. diphtheriae (De Zoysa et al., 1995) and C. pseudotuberculosis (Connor et al., 2000).

We used this method to test 162 isolates from bovine milk with high SCC from 57 herds in Northern Spain. All isolates had been identified as $C$. bovis by the API Coryne system (BioMeriéux, France) and by endonuclease restriction analysis of the 16S rRNA gene (Huxley et al., 2004). None of the 162 isolates showed a distinct restriction pattern from the reference strain $C$. bovis ATCC 7715.

Bacteria were grown in $2 \mathrm{~mL}$ of trypticase soy broth supplemented with $10 \%$ horse serum and $0.5 \%$ glycine until $\mathrm{OD}_{600}=1$. Cells were harvested by centrifugation, resuspended in $0.5 \mathrm{~mL}$ of Tris/HCl-EDTA (TE) buffer (10 $\mathrm{m} M$ Tris/ $\mathrm{HCl}, 1 \mathrm{~m} M$ EDTA, $\mathrm{pH}=8.0)$, and then mixed with an equal volume of $1 \%$ (wt/vol) low-melting point agarose (Bio-Rad, Hercules, CA) at $40^{\circ} \mathrm{C}$. Eighty microliters of the mixture was allowed to solidify in each of 5 plastic plug molds. Plugs were incubated for $24 \mathrm{~h}$ at $37^{\circ} \mathrm{C}$ in $2 \mathrm{~mL}$ of lysis solution [ $1 \mathrm{M} \mathrm{NaCl}, 10 \mathrm{mM}$ Tris/HCl, $0.5 \%$ sodium deoxycholate, $0.25 M$ EDTA, and $1 \mathrm{mg} / \mathrm{mL}$ of lysozyme (Sigma, St. Louis, MO)], followed by $24 \mathrm{~h}$ at $50^{\circ} \mathrm{C}$ in $2 \mathrm{~mL}$ of proteinase solution made up of $1 \mu \mathrm{g} / \mathrm{mL}$ of proteinase $\mathrm{K}$ (Sigma) in $0.25 M$ EDTA, $1 \%$ Sarkosyl. Plugs were subsequently washed in TE 4 
Table 1. Details of Corynebacterium bovis pulsed-field gel electrophoresis XbaI pulsotypes.

\begin{tabular}{|c|c|c|c|c|c|}
\hline Pulsotype & $\begin{array}{l}\text { Fragments } \\
\text { (no.) }\end{array}$ & $\begin{array}{l}\text { Approximate } \\
\text { genome size }(\mathrm{kb})^{1}\end{array}$ & $\begin{array}{l}\text { Number of } \\
\text { strains }(\%)\end{array}$ & $\begin{array}{l}\text { Number of } \\
\text { herds }(\%)\end{array}$ & $\begin{array}{l}\text { Other pulsotypes } \\
\text { in same herd }\end{array}$ \\
\hline I & 11 & 2902 & $84(51.9)$ & $36(63.2)$ & II (5), III (1), IV (4), V (1) \\
\hline II & 12 & 3099 & $48(29.6)$ & $13(22.8)$ & I (5), IV (2) \\
\hline III & 14 & 3535 & $5(3.1)$ & $5(8.8)$ & I (1), VI (2) \\
\hline IV & 9 & 2991 & $13(8.0)$ & $10(17.5)$ & I (4), II (2) \\
\hline V & 9 & 2217 & $3(1.9)$ & $1(1.8)$ & $\mathrm{I}(1)$ \\
\hline VI & 10 & 3015 & $8(4.9)$ & $5(8.8)$ & III (2) \\
\hline VII & 9 & 2102 & $1(0.6)$ & $1(1.8)$ & None \\
\hline
\end{tabular}

${ }^{1}$ Approximate genome sizes for each pulsotype were obtained by adding up the size of all its pulsed-field gel electrophoresis fragments.

${ }^{2}$ Twelve herds had 2 different pulsotypes, and one herd had 3 pulsotypes (I, II, and IV).

times for 30 min each and kept at $4^{\circ} \mathrm{C}$ in $\mathrm{TE}$ until further analysis. One-half of each plug was preincubated in $100 \mu \mathrm{L}$ of enzyme buffer for $1 \mathrm{~h}$ at room temperature and then digested with 30 units of $\mathrm{Xba \textrm {I }}$ (Roche, Switzerland) at $37^{\circ} \mathrm{C}$ for $4 \mathrm{~h}$ in a final volume of $100 \mu \mathrm{L}$. Digested DNA was subjected to electrophoresis using a CHEF-DR II apparatus (Bio-Rad) at $15^{\circ} \mathrm{C}$ for $24 \mathrm{~h}$ at $6 \mathrm{~V} / \mathrm{cm}$ with pulse times of 10 to $40 \mathrm{~s}$ (linear ramp). Concatamers of bacteriophage lambda DNA were used as molecular size standards. The gels were stained with $0.5 \mu \mathrm{g} / \mathrm{mL}$ of ethidium bromide and photographed under ultraviolet light. The reproducibility of the PFGE protocol was verified by processing multiple batches of some $C$. bovis isolates and the type strain ATCC 7715 . Numerical analysis of banding patterns was performed using the Quantity One software (Bio-Rad). The similarity between all pairs was assessed using the Dice coefficient correlation; UPGMA (unweighted pair group method) clustering was used to construct a dendrogram.

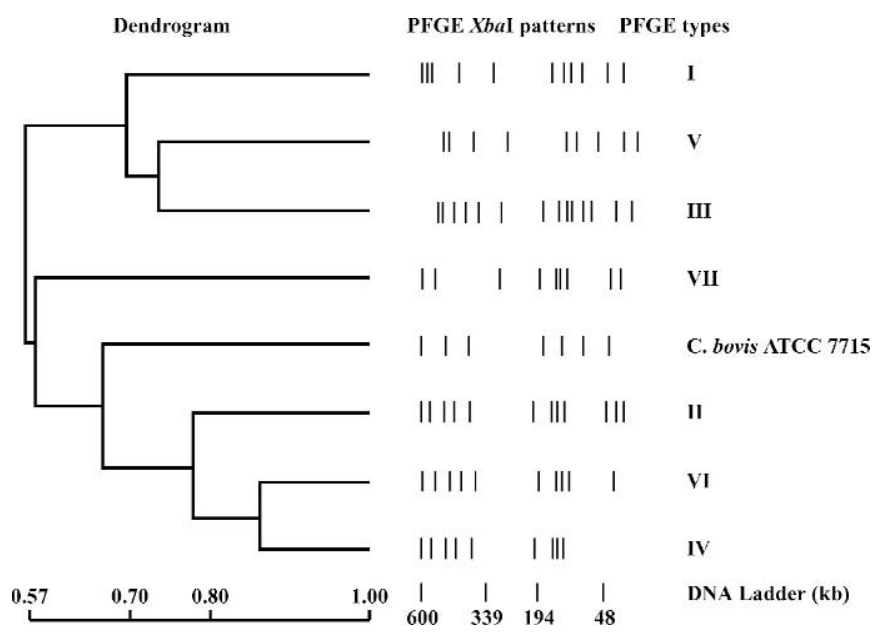

Figure 1. Dendrogram illustrating the genetic relatedness of the 7 pulsotypes found in 162 Corynebacterium bovis isolates and the type strain of $C$. bovis ATCC 7715. The scale indicates similarity. PFGE $=$ Pulsed-field gel electrophoresis.
Pulsed-field gel electrophoresis of $X b a \mathrm{I}$-restricted isolates generated 7 pulsotypes, each containing 9 to 14 restriction fragments ranging from 20 to $600 \mathrm{~kb}$ in size (Table 1; Figure 1). The most frequent pulsotype was pattern I (51.9\%; 84 isolates) followed by pulsotype II (29.6\%; 48 isolates). The rest of the pulsotypes (III to VII) contained between 1 and 13 isolates each. None of the pulsotypes resembled that of $C$. bovis ATCC 7715 . This could be explained by the different origin of the reference strain (American) and this study's isolates (European). However, no relationship was found between the geographical location of the herd and pulsotype among our isolates. Isolates from only 12 of the 57 herds yielded 2 different pulsotypes, whereas just 1 herd had 3 pulsotypes (I, II, and IV) isolated (Table 1). The finding that mixed infections are relatively rare in dairy herds suggests that pulsotype information can be a valuable epidemiological tool that deserves further investigation to clarify the real implications of $C$. bovis infection in mammary disease.

The average genome size of $C$. bovis was estimated to be $3 \mathrm{Mbp}$ by adding up the sizes of the linear fragments in each pulsotype. This is similar to the genome sizes of other Corynebacterium species such as C. glutamicum (3.31 Mbp; Correia et al., 1994) and C. diphtheriae (2.49 Mbp; Cerdeno-Tarraga et al., 2003). However, further analysis using more restriction enzymes is necessary to confirm this estimation of the C. bovis genomic size and to increase the discriminatory power of the PFGE technique.

In summary, we propose a method to type $C$. bovis isolates. This PFGE-based protocol clearly classified 162 C. bovis isolates from 57 dairy herds into 7 pulsotypes. This method provides information that may be very useful in the study of the epidemiology of $C$. bovis mastitis and other pathological conditions involving this species.

\section{ACKNOWLEDGMENTS}

Financial support was provided by Instituto Nacional de Investigación Agraria y Alimentaria (INIA, SC97- 
033). D. García-Crespo was the recipient of a fellowship from the Dpto. de Agricultura y Pesca of the Basque Government. We thank Idoia Ziluaga for her help collecting milk samples and isolating bacteria.

\section{REFERENCES}

Bernard, K. A., C. Munro, D. Wiebe, and E. Ongsansoy. 2002. Characteristics of rare or recently described corynebacterium species recovered from human clinical material in Canada. J. Clin. Microb. 40:4375-4381.

Boyer, P. 1998. Mastitis in dairy herds associated with Corynebacterium bovis. Vet. Rec. 143:175-176.

Cerdeno-Tarraga, A. M., A. Efstratiou, L. G. Dover, M. T. Holden, M. Pallen, S. D. Bentley, G. S. Besra, C. Churcher, K. D. James, A. De Zoysa, T. Chillingworth, A. Cronin, L. Dowd, T. Feltwell, N. Hamlin, S. Holroyd, K. Jagels, S. Moule, M. A. Quail, E. Rabbinowitsch, K. M. Rutherford, N. R. Thomson, L. Unwin, S. Whitehead, B. G. Barrell, and J. Parkhill. 2003. The complete genome sequence and analysis of Corynebacterium diphtheriae NCTC13129. Nucleic Acids Res. 31:6516-6523.

Connor, K. M., M. M. Quirie, G. Baird, and W. Donachie. 2000. Characterization of United Kingdom isolates of Corynebacterium pseudotuberculosis using pulsed-field gel electrophoresis. J. Clin. Microb. 38:2633-2637.

Correia, A., J. F. Martin, and J. M. Castro. 1994. Pulsed-field gel electrophoresis analysis of the genome of amino acid producing corynebacteria: Chromosome sizes and diversity of restriction patterns. Microbiology 140:2841-2847.

De Zoysa, A., A. Efstratiou, R. C. George, M. Jahkola, J. VuopioVarkila, S. Deshevoi, G. Tseneva, and Y. Rikushin. 1995. Molecular epidemiology of Corynebacterium diphtheriae from northwestern Russia and surrounding countries studied by using ribotyping and pulsed-field gel electrophoresis. J. Clin. Microb. 33:10801083 .

Hillerton, E. J. 2000. Mastitis control in member countries. United Kingdom Mastitis Newsl. 24:40-42.

Huxley, J. N., C. R. Helps, and A. J. Bradley. 2004. Identification of Corynebacterium bovis by endonuclease restriction analysis of the 16S rRNA gene sequence. J. Dairy Sci. 87:38-45.

Lam, J. G. M., Y. H. Schukken, J. H. van Vliet, F. J. Grommers, M. J. M. Tielen, and A. Brand. 1997. Effect of natural infection with minor pathogens on susceptibility to natural infection with major pathogens in the bovine mammary gland. Am. J. Vet. Res. $58: 17-22$.

Schukken, Y. H., K. E. Leslie, D. A. Barnum, B. A. Mallard, J. H. Lumsden, P. C. Dick, G. H. Vessie, and M. E. Kehrli. 1999. Experimental Staphylococcus aureus intramammary challenge in late lactation dairy cows: Quarter and cow effects determining the probability of infection. J. Dairy Sci. 82:2393-2401.

Singleton, P. 2000. Nucleic-acid-based typing, Pages 168-202 in DNA Methods in Clinical Microbiology. P. Singleton, ed. Kluwer Academic Publishers, Dordrecht, The Netherlands.

Watts, J. L. 1988. Etiological agents of bovine mastitis. Vet. Microbiol. 16:41-66. 